\title{
Beta-Lactamase Production Among Uropathogens in Patients Attending Some Hospitals in Kano, Nigeria
}

\author{
Hamza Sule, Abdulhadi Sale Kumurya \\ Department of Medical Laboratory Science, Faculty of Allied Health Sciences, Bayero University, Kano, Nigeria
}

Email address:

sule.hamza@yahoo.com (H. Sule)

To cite this article:

Hamza Sule, Abdulhadi Sale Kumurya. Beta-Lactamase Production Among Uropathogens in Patients Attending Some Hospitals in Kano, Nigeria. International Journal of Biomedical Materials Research. Vol. 4, No. 3, 2016, pp. 58-62. doi: 10.11648/j.ijbmr.20160403.18

Received: August 19, 2016; Accepted: December 2, 2016; Published: January 4, 2017

\begin{abstract}
Ability of bacteria to withstand antibiotic therapy is often associated with resistance. Certain bacteria have the ability to produce some enzymes, like Beta-Lactamase, which confers resistance to some groups of antibiotics like penicillins and cephalosporins. The study focused on producers of these enzymes among uropathogens. A total of one hundred and forteen isolates (114) were screened, out of which seventy one $71(62.3 \%)$ were found positive for the enzymes. Eschericia coli had the highest positivity rate $40(56.3 \%)$. Followed by Klebsiella spp., Staphylococcus aureus, Staphylociccus saprophyticcus, Proteus mirabilis, and Pseudomonas aeruginosa with 15 (21.1\%), 7 (10.0\%), 5 (7.0\%), 3 (4.2\%), and 1 (1.4\%) respectively. In the same vein, it was discovered that, isolates of females' origin, produced more of the enzymes than those of their males counterpart. This was indicated by the production of the enzyme by at least one isolate in each of the species isolated from female samples while in males, some species did not even produce any of the enzymes. Age-wise distribution of the enzymes showed that, 21-30, and 31-40 age groups had all the isolates producing the enzymes in varying frequencies. Only Pseudomonas aeruginosa that produced its enzyme outside these age groups. Isolates of females origin had more of the enzymes produced in all the species compared to those from males, with ratios of; 26:14, 11:4, 5:2, 3:2, 2:1, and 1:0 for, $E$ coli, Klebsiella species, Staphylococcus aureus, Staphylococcus saprophyticus, Proteus mirabilis, and Pseudomonas aeruginosa respectively.
\end{abstract}

Keywords: Urinary Tract Infections, Uropathogens, Beta-Lactamase, Kano

\section{Introduction}

Urinary tract infections have been one of the major causes of diseases in human history. Worldwide, about 150 million people are diagnosed with UTI each year, costing the global economy in excess of six billion US dollars (Foxman et al., 2000). It was thought that, with the introduction of antibiotics, these problems and related others are to be over. However, it was, and still remains surprising that, bacteria has been able to evolved mechanisms that helps them inactivate and/or bypass some of the activities of antibiotics. There is therefore the need for concerted efforts to prevent the emergence of new resistant strains and the spread of already existing ones (Senka džidić et al. 2008). Among the part of armory in the arsenal of these bacteria, are the enzymes beta-lactamases. Beta-lactamase are enzymes produced by some bacteria and are responsible for their resistance to certain groups of antibiotics, like penicillins, cephalosporins and carbapenem (Bush, et al., 1995) $\beta$-lactamase deactivates $\beta$-lactam antibiotics, by breaking and opening their common molecular structure ( $\beta$ - lactam ring). Some of these enzymes include extended spectrum $\beta$-lactamase (ESBL), and carbapenemase. The first $\beta$-lactamase was detected during the 1960s (Datta et al., 1965). Urinary tract infection (UTI) is the second most common infection after respiratory tract infections in many parts of the world (Mansour, et al., 2009). UTI is most commonly caused by various species of Escherichia, Klebsiella, Bacillus, Enterobacter, Pseudomonas, Enterococcus faecalis and Candida albicans (Abigail and Dixie, 2005; Rai et al., 2008). Up to $70 \%$ of pregnant women develop glucosuria, which encourage bacterial growth in the urine, hence aggravating the scourge of urinary tract infection (Al-Issa, 2009). Uropathogens have shown a slow but steady increase in resistance to several antibiotics over decades. Extendedspectrum beta-lactamases (ESBL) producing 
Enterobacteriaceae, are among the most problematic multidrug resistance (MDR) bacteria worldwide (Romero et al., 2005).

ESBLs are the beta-lactamases capable of hydrolyzing penicillin, broad-spectrum cephalosporins, and monobactams, and are generally derived from TEM and SHV-type enzymes but, may not affect cefamycins and carbapenems. ESBLs are often located on plasmids that are transferable from strain to strain and between bacterial species (Rupp and Fey 2003). Extended-spectrum $\quad \beta$-lactamase $\quad$ (ESBL)-producing Enterobacteriaceae have become widespread in hospitals and are increasing in community settings where they cause a variety of infections including UTI. In addition to hydrolyzing most $\beta$-lactam agents, bacteria harboring these enzymes display resistance to other unrelated antimicrobial agents and thus often poses a therapeutic dilemma (Maina et al., 2013). Extended-spectrum $\beta$-lactamases (ESBLs) are a rapidly evolving group of $\beta$-lactamases which also have the ability to hydrolyze third-generation cephalosporins and aztreonam, yet, are inhibited by clavulanic acid (Bush et al., 1995).

The persistent exposure of the bacterial strains to $\beta$-lactam related antibiotics has induced dynamics, continuous production and mutations of $\beta$-lactamase among uropathogens, these expands their activity even against the third and fourth generation cephalosporins. These new $\beta$ lactamases are called extended spectrum $\beta$-lactamases (Samaha-Kfoury et al., 2003). Antimicrobial resistance among bacterial strains is an emerging problem worldwide. Urinary tract infections (UTIs) are one of the high ranked bacterial infections in humans, both in the community and hospital settings (Cox, 1988; Gonzalez, 1999; Ullah et al., 2009). Class C Beta-lactamase enzymes are primarily chromosomal and plasmid-mediated. The most prevalent enzyme in this group, which is found among the Enterobacteriaceae and P. aeruginosa, is AmpC. Class C Beta-lactamases are resistant to Beta-lactamase inhibitors and mutations in the regulatory gene, which occurs at a high frequency among Enterobacter cloacae, and can result in high-level constitutive production resulting in resistance to all Beta-lactams except carbapenems (Livermore et al., 2004). Gram negative Enterobacteriaceae expressing AmpC and Extended-Spectrum-Beta-Lactamases are among the most multi-drug-resistant pathogens in hospitals and they are spreading worldwide (Ben-Ami et al., 2009).

\section{Materials and Methods}

\subsection{Study Area}

The study was conducted in three selected hospitals in Kano metropolis. The hospitals were: Murtala Mohammad Specialist Hospital, Kano, located near the amir's palace. Infectious Disease Hospital Kano, along France road which leads to Katsina road, and Sir Mohammad Sunusi Hospital, Kano, behind the Kano Eastern bypass, along Hadejia road, one of the largest town in Jigawa state. The major activity in the city is commercial in nature, but some are farmers and civil servants alike.

\subsection{Specimen Collection}

The patients were provided with universal bottles, into which they produced the required samples (i.e. clean catch midstream urine). Because, the first flow of urine usually wash-up the urethra, flushing anything that might be on the way including contaminants. This gives the subsequent urine that flow a true representation of what the bladder contained. Fifteen millilitre of urine samples were collected from each patient. All samples were immediately processed. But samples that could not be processed immediately were refrigerated at $4^{\circ} \mathrm{C}$ before processing.

\subsection{Specimen Processing and Isolation of the Uropathogens}

All samples, were examined macroscopically to checkout for colour, turbidity and /or blood tinge as the case may be. The uncentrifuged urine samples were mixed by rotating the container before inoculating on to Cystein Lactose Electrolyte Deficient Agar (CLED) and Blood Agar by streak method (Cheesebrough, 2000), and later incubated at $37^{\circ} \mathrm{C}$ for 24 hours.

Some of the samples inoculated by streak method yielded colonies after 24 hours, which were subcultured on to MacConkey agar plate to obtain discrete colonies for further characterization and identification.

\subsection{Identification and Characterization of the Isolates}

Pure culture from purity plates (using MacConkey agar) containing discrete colonies of the isolates were used for the identification. The identification was based on colonial morphology and biochemical characteristics. Colonies produced after 24 hours (on purity plates) were physically examined for observable characters like size, shape, consistency, colour, opacity and effect on media i.e lactose or non lactose fermentation habit. Additionally motility, Gram staining reaction, and biochemical tests were used in characterizing the isolates from the purity plates (Mackey and McCartney, 1996).

\subsection{Determination of Beta-Lactamase Production by the Isolates}

Beta-lactamase production by isolates was determined using standard acidometric method, which was based on the detection of penicilloic acid produced due to the breakdown of penicillin by beta-lactamases. The penicilloic acid was detectable by change in colour from purple to yellow of the indicator, bromocresol purple (contained in the buffered crestaline penicillin bromocresol purple solution. (Cheesebrough, 2000).

Statistical analysis: The data obtained was analysed using ANOVA and Chi Squire tests $\left(\mathrm{X}^{2}\right)$

\section{Results}

Total of one hundred and forteen (114) isolates were used to determined beta-lactamases producers among 
uropathogens, of which seventy one $71(62.3 \%)$ were found to be producers of the enzymes (Table 1). The results also revealed that among the isolates involved, those obtained from females subjects produced more of the enzymes than the ones received from males, with a total of 50 and 21 isolates respectively (Table 2). Distribution of the enzyme across the age groups involved indicated that, age limits of 21-30 and 30-41, had at least one isolate producing the enzymes in all the screened species with the exception of Peudomonas aeruginosa while none of the isolates produce the enzymes in the age bracket of $\geq 71$ (Table 3 ). Females to males ratio in terms of the enzymes production per species per gender confirmed isolates of females origin having the upper hand with regards to production of the enzymes throughout the work (Table 4).

Table 1. Beta-lactamase production by the isolates.

\begin{tabular}{lllllll}
\hline & E. coli & K. pneu. & S. aur. & S. sapr. & P. mir. & Ps. aer \\
\hline Total No. & 58 & 27 & 8 & 11 & 8 & 2 \\
B-L Producers & 40 & 15 & 7 & 5 & 3 & 114 \\
Percentage & 56.3 & 21.1 & 10.0 & 7.0 & 71 & 1 \\
\hline
\end{tabular}

KEY:

B-L Beta Lactamase

NE. coli=Escherichia coli

K. pneu.=Klebsiella pneumoniae

S. aur. $=$ Staphylococcus aureus

S. sapr $=$ Staphylococcus saprophyticus

P. mir. $=$ proteus mirablis

Ps. aer.=pseudomonas aeruginosa

Table 2. Distribution of the enzymes with respect to gender.

\begin{tabular}{lllllll}
\hline & Eschericia coli & $\begin{array}{l}\text { Klebsiella } \\
\text { pneumoniae }\end{array}$ & $\begin{array}{l}\text { Staphylococcus } \\
\text { aureus }\end{array}$ & $\begin{array}{l}\text { Staphylococcus } \\
\text { saprophyticus }\end{array}$ & $\begin{array}{l}\text { Proteus } \\
\text { mirabilis }\end{array}$ & $\begin{array}{l}\text { Pseudomonas } \\
\text { aeruginosa }\end{array}$ \\
\hline No. of isolates & 58 & 27 & 8 & 11 & 8 & 2 \\
B/L (+) isolates & 40 & 15 & 7 & 5 & 3 & 114 \\
Females & 26 & 11 & 5 & 4 & 3 & 1 \\
Males & 14 & 4 & 2 & 1 & 50 & 0 \\
\hline
\end{tabular}

Key:

$\mathrm{B} / \mathrm{L}=$ Beta-lactamase

$(+)=$ Positive

Table 3. Distribution of beta-lactamase production across the age groups.

\begin{tabular}{ll|lll|l}
\hline Age Group & Eschericia coli & $\begin{array}{l}\text { Klebsiella } \\
\text { pneumoniae }\end{array}$ & $\begin{array}{l}\text { Staphylococcus } \\
\text { aureus }\end{array}$ & $\begin{array}{l}\text { Staphylococcus } \\
\text { saprophyticus }\end{array}$ & $\begin{array}{l}\text { Psedomonas } \\
\text { Aeruginosa }\end{array}$ \\
\hline$\leq 10$ & 4 & 1 & 0 & 0 & 0 \\
$11-20$ & 5 & 3 & 2 & 1 & 0 \\
$21-30$ & 10 & 5 & 3 & 2 & 1 \\
$31-40$ & 6 & 1 & 1 & 1 & 1 \\
$41-50$ & 5 & 3 & 1 & 1 & 0 \\
$51-60$ & 6 & 2 & 0 & 0 & 0 \\
$61-70$ & 4 & 0 & 0 & 0 & 0 \\
$\geq 71$ & 0 & 0 & 0 & 0 & 0 \\
Total & 40 & 15 & 7 & 5 & 0 \\
\hline
\end{tabular}

Table 4. Distribution of beta-lactamase among the isolates in relation to gender.

\begin{tabular}{|c|c|c|c|c|c|c|c|c|c|c|c|c|}
\hline \multirow[t]{2}{*}{ Age Group } & \multicolumn{2}{|c|}{ Eschericia E. coli } & \multicolumn{2}{|c|}{$\begin{array}{l}\text { Klebsiella } \\
\text { pneumoniae }\end{array}$} & \multicolumn{2}{|c|}{$\begin{array}{l}\text { Staphylococcus } \\
\text { aureus }\end{array}$} & \multicolumn{2}{|c|}{$\begin{array}{l}\text { Staphylococcus } \\
\text { saprophyticus }\end{array}$} & \multicolumn{2}{|c|}{ Proteus mirabilis } & \multicolumn{2}{|c|}{$\begin{array}{l}\text { Psedomonas } \\
\text { aeruginosa }\end{array}$} \\
\hline & $\mathrm{F}$ & M & $\mathrm{F}$ & $\mathrm{M}$ & $\mathrm{F}$ & $\mathrm{M}$ & $\mathrm{F}$ & $\mathrm{M}$ & $\mathrm{F}$ & M & $\mathrm{F}$ & $\mathrm{M}$ \\
\hline$\leq 10$ & 3 & 1 & 1 & 0 & 0 & 0 & 0 & 0 & 0 & 0 & 0 & 0 \\
\hline $11-20$ & 3 & 2 & 2 & 1 & 2 & 0 & 0 & 1 & 0 & 0 & 0 & 0 \\
\hline $21-30$ & 7 & 3 & 5 & 0 & 3 & 0 & 2 & 0 & 1 & 0 & 0 & 0 \\
\hline $31-40$ & 4 & 2 & 1 & 0 & 1 & 0 & 0 & 1 & 0 & 1 & 0 & 0 \\
\hline $41-50$ & 3 & 2 & 2 & 1 & 0 & 1 & 1 & 0 & 1 & 0 & 0 & 0 \\
\hline $51-60$ & 3 & 3 & 1 & 1 & 0 & 0 & 0 & 0 & 0 & 0 & 1 & 0 \\
\hline $61-70$ & 3 & 1 & 0 & 0 & 0 & 0 & 0 & 0 & 0 & 0 & 0 & 0 \\
\hline$\geq 71$ & 0 & 0 & 0 & 0 & 0 & 0 & 0 & 0 & 0 & 0 & 0 & 0 \\
\hline Total & 26 & 14 & 12 & 3 & 6 & 1 & 3 & 2 & 2 & 1 & 1 & 0 \\
\hline
\end{tabular}




\section{Discussion}

Seventy one $71(62.3 \%)$ of the one hundred and forteen (114) screened isolates produced the enzymes BetaLactamases. Escherichia coli was found to be the heights producer of the enzyme $40(56.3 \%)$, followed by Klebsiella pn eumonia 15 (21.1\%), Staphylococcus aureus, 7 (10.0\%) Staphylococcus saprohyticus, 5 (7.0\%), Proteus mirabilis 3 (4.2), and pseudomonas aeruginosa. 1 (1.4\%). Chander and Shrestha (2013), also found, in a tertiary care hospital in Kathmandu, Nepal, that, E. coli has the highest frequency of the enzyme production, in which 60 out of 444 isolates produce the enzymes followed by Klebsiella pneumonia with 24 out of 145 isolates producing the enzyme. These proved these two uropathogens to be among the front runners as far as the production of these enzymes is concern. A similar pattern was observed Gaurav, (2012) in clinical isolates of a tertiary hospital, Jhalawar, Rajasthan, India. But with higher percentages than found in this study, where E. coli, led in the production rate $(73 \%)$, Klebsiella pneumniae, Proteus mirabilis, and Pseudomonas followed in that order (58\%), $(50 \%)$ and $(37 \%)$ respectively. These relative differences in terms of higher percentages, especially, that of Pseudomonas aeruginosa could be due to locality differences. More so, Pseudomonas is a well known or prominent nosocomial pathogen, therefore, hospitalized patients may be the source of its higher percentage in the clinical samples they reported to have used.

Another study on uropathogens which involved pregnant women, Thapa et al. (2015), also found similar trend, were the beta-lactamases enzymes production per isolates of the uropathogens revealed 78, 26, 24, and 1, isolate (s) for; $E$. coli, Klebsiella species, Proteus mirabilis and Pseudomonas aeruginosa respectively.

Beta-lactamase production with respect to gender revealed higher production of the enzymes by the isolates from female patients 50 than those isolates from male patients 21 . A study in 2013, Chander and Shrestha also favoured this outcome, were 51 and 33 were the beta-lactamase production rates for isolates from females and males in their study respectively. Similar findings was also reported, Alabi et al. (2014), in a study titled Prevalence of extended-spectrum $\beta$-lactamase producing isolates from asymptomatic bacteriuria among students in a tertiary institution in Ibadan, Nigeria. Where beta-lactamases production by isolates of males origin were 34 while those from females samples were 40 respectively.

On the enzyme gender correlation also, production of betalactamases by uropathogens, was reported in 2013, in research conducted, in a Tertiary-care hospital in Kathmandu, Nepal, on two of the most important uropathogens that normally produces the enzymes with significant rate (E. coli and Klebsiella speces). The work revealed 36 and 24 for $E$. coli and Klebsiella isolates that produced the enzymes from female urine samples while 15 , and 9 were the E. coli and Klebsiella spp isolates that produce the enzyme from urine samples of male subjects respectively (Chander et al., 2013).
According to age groups, it was discovered in this study that, age bracket of 21-30, a highly active group (sexually) who are also most likely to toy with risk factors of UTI, had the highest frequency of isolation and corresponding betalactamases production, because the group had $10 \mathrm{E}$. coli, 5 Klebsiella pneumonia, 3 Staphylococcus aureus, 2 Staphylococcus saprophyticus and 1 Proteus mirabilis as beta-lactamase producers. This compares favourably (Kapur, et al., 2015), in which 30-45, also sexually active age range had the highest production rate of the enzymes among the age groups used in their study, with up to $(43.75 \%)$ of the Beta-lactamases producing uropathogens belonging to the group. Beta-lactamase production by the uropathogens in relation to gender, revealed isolates of females origin having much of the enzymes compared to those from males. It also indicated E. coli and Klebsiella pneumoniae as the predominant uropathogens among the screened species $26: 14$ as female to male ratio, total (40), and 11:4 as female to male ratio, total (15), for E. coli and Klebsiella isolates respectively. This is in line with the findings in Nepal (Chander and Shrestha, 2013) in which E. coli had a sub total of (36) and (24) isolates for females and males subjects with (60) as the total and Klebsiella pneumoniae isolates (15) and (9) for females and males with corresponding (24) as the total in the same manner.

\section{Recommendations}

Screening of beta-lactamases (enzymes) is highly recommended because of the growing evidence of its production among conventional and nonconventional Uropathgens. It is also important that, screening for the enzymes becomes a research priority if not a routine activity in private and public hospitals, especially in the study area.

\section{Conclusion}

Rampant display of resistant factors like beta-lactame among uropathogens is alarming and is sending strong signals to health care managers for urgent action. It can therefore be concluded that recurrent and persistent cases of UTI especially in women are artibutable to these factors including beta-lactamase production by the uropathogens.

\section{Acknowledgement}

We thank the management of Wudil General Hospital, Kano, for allowing us to carry out the research in their facility. Our sincere gratitude also goes to the Head of the Laboratory Department of the Hospital, and all other staff.

\section{Ethical Issues}

Permission was obtained from the ethical committee of Wudil General Hospital before embarking on the research. 


\section{References}

[1] Abigail, A. Dixie; W. (2005). Bacterial Pathogenesis: A Molecular approach, Washington DC ASM Press,. 2005.

[2] Alabi, O. S., Onyenwe, N. E. Satoye, K. A. and Adeleke, O. E. (2014). Prevalence of extended-spectrum $\beta$-lactamase producing isolates from asymptomatic bacteriuria among students in a tertiary institution in Ibadan, Nigeria. Nature and Science 12 (4): 113.

[3] Al-Issa, M. (2009). Urinary tract infection among pregnant women in north Jordan. Middle East J Fam Med., 7: 10-4.

[4] Ben-Ami, R., Rodriguez-Bafio, J., Calbo E. S. And Arslan, H. A. (2009). Multinational survey of risk factors for infection with extended spectrum beta lactamasesmproducing Enterobacteriaceae in non hospitalized patients. 5 (1): 49-51.

[5] Bush, K., Jacoby, G. A. and Medeiros, A. A. (1995). A Functional Classification Scheme for $\beta$ - lactamases and its Correlation with Molecular Structure. Antimicrob. Agents Chemother. 39: 1211-33.

[6] Chaliha, C. Stanton, S. L., (2002). Urological problems in pregnancy. BJU Int., 89 (5): 469-76. To remove

[7] Chander and Shrestha, (2013). Prevalence of extended spectrum beta lactamase producing Escherichia coli and Klebsiella pneumoniae urinary isolates in a tertiary care hospital in Kathmandu, Nepal. BMC Research Notes 6: 487.

[8] Cheesebrough, M. (2000). Distric Laboratory Practice in Tropical Countries Low Price ed. Chambridge University Press. Pp. 434.

[9] Cox, C. E. (1988). Nosocomial urinary tract infections. Urol, 32 (3): 210-215.

[10] Datta, N. and Kontomichalou, P. (1965)."Penicillinase synthesis controlled by infectious $\mathrm{R}$ factors in Enterobacteriaceae." Nature 208: 239-41.

[11] Foxman, B., Barlow, R., D’Arcy, H., Gillespie, B., and Sobel, J. D. (2000). Urinary tract infection: Self-reported incidence and associated costs. Ann Epidemiol; 10 (8): 509-15.

[12] Gaurav, Dalela (2012). PREV. of Extended Spectrum BetaLactamase (ESBL) Producers among Gram Negative Bacilli from Various Clinical Isolates in a Tertiary Care Hospital at Jhalawar, Rajasthan, India. Journal of Clinical and Diagnostic Research. 6 (2): 182-187.

[13] Gonzalez, C. M., and Schaeffer, A. J. (1999). Treatment of urinary tract infection: what's old, what's new, and what works. World J Urol.; 17 (6): 372-382.
[14] Kapur, A., Ahmed, M. S., and John, S. (2015). Prevalence of Extended-Spectrum Beta-Lactamase-Producing Pathogens From Urinary Tract Infected Samples and Their Sensitivity Pattern Against Withania somnifera. Int J Infect. 2 (1): e22664.

[15] Livermore, D. M. and Woodford, N. (2004). Laboratory detection and reporting of bacteria with extended spectrum betalactamases. Antibiotic resistance monitoring and reference laboratory, specialist and reference. Microbiology division, Health Protection Agency -Colindale, London.

[16] Maina, D., Makau, P., Nyerere, A. and Revathi, G. (2013). Antimicrobial resistance patterns in extended-spectrum $\beta$ lactamase producing Escherichia coli and Klebsiella pneumoniae isolates in a private tertiary hospital, Kenya. Microbiology Discovery, 1 (5): $1-4$ http://dx.doi.org/10.7243/2052-6180-1-5.

[17] Mansour, A. Manijeh, M. and Zohreh, P. (2009). Study of bacteria isolated from urinary tract infections and determination of their susceptibility to antibiotics. Jundishapur J Microbiol; 2 (3): 118-23.

[18] Mackey, McCartney, (1996). Tropical Medical Micrbiology 14th ed. Churchill Livingstone. London. Pp. 978.

[19] Rai, G. Upretin, H., Rai, S., Saha, K. and Shrestha, R. (2008). Nepal Med Coll J. 10, 86.

[20] Romero, L., López, L., Rodríguez-Baño, J., Ramón, Hernández, J., Martínez-Martínez, L., and Pascual, A. (2005). Long-term study of the frequency of Escherichia coli and Klebsiella pneumoniae isolates producing extended-spectrum beta-lactamases. Clin Microbiol Infect.; 11 (8): 625-31.

[21] Rupp, M. E., and Fey, P. D. (2003). Extended spectrum betalactamase (ESBL)-producing Enterobacteriaceae: Considerations for diagnosis, prevention and drug treatment. Drugs; 63 (4): 353-65.

[22] Samaha-Kfoury, J. N., Araj, G. F. (2003). Recent developments in $\beta$-lactamases and extended spectrum $\beta$ lactamases. $B M J$; 327: 1209-13.

[23] Senkas-Dzidic, J., and Suskovic., B., (2008). Kos, Food Technolo. Biotechnolo., 46, 11.

[24] Thapa, R., Pramila, L., Megha, Raj, B., and Ganesh, P. A. (2015). Prevalence of extended spectrum beta lactamase producing uropathogens in pregnant women. Asian $J$ Pharm Clin Res, 8 (1), 2015, 207-210.

[25] Ullah, F., Malik, S. A, Ahmed J. (2009): Antibiotic susceptibility pattern and ESBL prevalence in nosocomial Escherichia coli from urinary tract infections in Pakistan. Afr J Biotechnol, 8 (16): 3921-3926. 